\title{
Knowledge, Attitude and Behaviors of People about Human Papillomavirus (HPV) and HPV Vaccine: A Single-Center Cross-Sectional Study
}

\section{Toplumun Human Papilloma Virus (HPV) ve HPV Aşısı Hakkındaki Bilgi, Tutum ve Davranışları: Tek Merkezli Kesitsel Çalışma}

\author{
Gökçe TURAN $^{1}(\mathbb{D})$, Gülnur KUL ${ }^{2}$ (D) , Yağmur SOYKAN ${ }^{1}$ (D) \\ ${ }^{1}$ Gazi University, School of Medicine, Department of Obstetrics and Gynecology, Ankara, TURKEY \\ 2 Kırıkhan State Hospital, Infectious Diseases Clinic, Hatay, TURKEY
}

\section{Abstract}

Background: This study aimed to evaluate the knowledge, attitude and behaviors of people about human papillomavirus (HPV) infection and the HPV vaccine.

Materials and Methods: An in-depth questionnaire that evaluated the knowledge, attitudes, and behaviors about HPV and the HPV vaccine was administered to participants admitted to the clinic of a second-line hospital between June 2019 and December 2019 in this cross-sectional study.

Results: A total of 836 participants admitting to various clinics of a second-line hospital between June 2019 and December 2019 were included in the study. The mean age of participants was $36.29 \pm 9.03,86 \%$ were women, $44 \%$ were university graduates, and $44 \%$ had post-graduate degrees. A total of $73 \%$ (n: 611 ) said that they never had a gynecological examination, and $73 \%$ ( $n: 613$ ) said "Yes, it is infected through sexual intercourse" to the question "How HPV is infected?" Among the participants, $67 \%$ ( $n$ : 565 ) of the patients knew the relationships between HPV and cervical cancer, and $71 \%$ ( $n$ : 594) were aware that "cervical cancer is a disease that can be prevented with the HPV vaccine." A total of $56 \%$ ( $n$ : 336) of participants said that they heard about the HPV vaccine from their doctors, and only $8 \%$ knew that the HPV vaccine was not included in the vaccination program of the Ministry of Health. Among them, $43 \%$ of the patients (n: 365$)$ said that they did not think of having the HPV vaccine for themselves, their spouses, or their children. Although $11 \%(n: 96)$ said that they would not have the vaccine even if the vaccine was provided free-of-charge by the state, and $31 \%$ ( $n: 264$ ) said that they could have the vaccine in case it was provided free-of-charge by the state.

Conclusions: Our patient population lacks knowledge on the fact that cervical cancer is a disease that can be prevented by the HPV vaccine, how the HPV virus causes infections, and on how precautions must be taken. The main reason for this is that the vaccine is not included in the routine vaccination program in our country, healthcare staff cannot provide adequate information for patients on the infection and vaccine of HPV, and the price of the vaccine is expensive relative to the conditions of our country. The underlying reasons for the inadequate information of healthcare institutions or staff in informing people on the HPV vaccine can be studied in detail.

Key Words: Cervical cancer, Human Papillomavirus, Level of knowledge, Questionnaire, Vaccination

Öz.

Amaç: Amacımız bölgemizdeki hasta popülasyonun Human papillomavirüs (HPV) enfeksiyonu ve HPV aşısı hakkındaki bilgi, tutum ve davranışlarının incelenmesidir.

Materyal ve Metod: Bu kesitsel çalışmada, Haziran 2019 ve Aralık 2019 ayları arasında ikinci basamak bir hastanenin polikliniğine başvuran katılımcılara HPV ve HPV aşısı hakkındaki bilgi tutum ve davranışlarını değerlendiren ayrıntılı bir anket uygulandı.

Bulgular: Haziran 2019 ve Aralık 2019 ayları arasında ikinci basamak bir hastanenin çeşitli polikliniklerine başvuran 836 katılımcı çalışmaya dahil edildi. Bu katılımcıların ortalama yaşları $36.29 \pm 9.03$ idi ve \%86'sı kadın, \%44'ü üniversite mezunu, \%44'ü yüksek lisans mezunuydu. \%73'ü (n: 611) hiç jinekolojik muayene gitmediğini belirtirken, \%73'ü (n: 613) HPV'nin nasıl bulaştığı sorusuna "evet, cinsel ilişki ile bulaşı" cevabını verdi. HPV ve serviks kanseri arasındaki ilişkiyi hastaların \%67'si (n: 565) biliyorken, \%71'i de (n: 594) "serviks kanserinin HPV aşısı ile önlenebilir bir hastalık olduğunu farkındaydı. \%56'sı (n:336) HPV aşısını doktorundan duyduğunu belirtirken, sadece \%8'i HPV aşısının Sağlık Bakanlığı'nın aşı programında yer almadığını biliyordu. \%43 hasta ( $\mathrm{n}$ : 365) kendisine, eşine veya çocuklarına HPV aşısı yaptırmayı düşünmediğini belirtti. \%11'i (n:96) aşının devlet tarafından ücretsiz karşılansa dahi yaptırmayacağını bildirirken, \%31'i (n:264) aşının devlet tarafından ücretsiz karşılanması durumunda aşıyı yaptırabileceğini belirtti.

Sonuç: Bizim hasta popülasyonumuzda serviks kanserinin HPV aşısı ile önlenebilir bir hastalık olduğu, HPV virüsünün nasıl bulaştığı ve nasıl önlem alınması gerektiği konusunda bilgi eksikliği vardır. Bunun ana sebebi aşının ülkemizde rutin aşı takvimine alınmaması, sağılı çalışanlarının hastalara HPV aşısı ve enfeksiyonu hakkında yeterli bilgi verememesi ve aşı ücretinin ülkemiz şartlarında pahalı olmasından kaynaklanmaktadır. Sağlık hizmeti veren kurumların veya kişilerin HPV aşısı hakkında bilgilendirmesindeki yetersizliğinin altında yatan sebepler ayrıntılı sorgulanabilir.

Anahtar kelimeler: Anket, Aşı, Bilgi düzeyi, Human Papillomavirus, Servikal kanser

\section{Sorumlu Yazar/Corresponding Author}

\section{Dr. Gokce TURAN}

Gazi University, School of Medicine, Department of Obstetrics and Gynecology, Ankara, TURKEY

E-mail: drgokceturan@gmail.com

Geliş tarihi / Received: 15.03.2021

Kabul tarihi / Accepted: 19.06.2021

DOI: $10.35440 /$ hutfd. 897050 


\section{Introduction}

Human papillomavirus (HPV) is the most common sexually transmitted infection (1). After transmission, HPV may cause cervical precancerous lesions and cervical cancers. About $99.7 \%$ of cervical cancers are associated with HPV (2). Cervical cancer is the second most-common cancer among women worldwide, and accounts for $6.6 \%$ of all cancers (3). There are more than 200 HPV types, but only specific types are oncogenic. It has been reported that the risk of being infected with HPV can reach up to $80 \%$ in a lifetime, about $90 \%$ of this rate disappears in 2 years and $5-10 \%$ may cause persisted disease (4). The malignant transformation process lasts about 5-30 years (4).

Although screening programs are commonly used, the reason why cervical cancer is still often seen is insufficiency in primary and secondary prevention. Limiting the number of sexual partners and using barrier methods play a crucial role in the prevention from cervical cancer. While vaccination is used for primary prevention, smear screening is used for secondary prevention. Vaccination of $90 \%$ of girls up to the age of 15 against HPV is among the 2030 control targets of the World Health Organization (5).

There are 3 types of the HPV vaccine. Quadrivalent HPV vaccine (Gardasil 4) which is effective against type 6, 11, 16 , and 18 was approved by the FDA in 2006 and bivalent HPV vaccine (Cervarix) which is effective against type 16 and type 18 was approved by the FDA in 2009 (6). Gardasil 9, which is a nonavalent HPV vaccine was developed against HPV Types of $6,11,16,31,33,45,52$, and 58, and was approved by the FDA in 2014. It also prevents HPV Type 9. Quadrivalent HPV vaccine obtained a license in Turkey in 2007 and bivalent HPV vaccine in 2008. Nonavalent HPV vaccine obtained a license in our country in 2019, but it is still not available in Turkey. As of 2014, the Centers for Disease Control updated the (Gardasil ${ }^{\circledR}$ ) HPV Vaccine Program as $0.5 \mathrm{ml}$. intramuscularly for girls between the ages of 9-14 in months 0 and 6 in 2 doses, and in 3 doses for women older than the age of 15 in months 0,2 , and 6 (7). The catch-up age range of the HPV vaccine is basically administered in 3 doses is from 13 to 26 . When administered before sexual activity starts, the vaccine has been found to be $100 \%$ preventive against cancer lesions and persistent infections (8). There is no national vaccination program for HPV in our country, but Turkish Gynecology/Oncology Association recommends the HPV vaccine. This study aimed to investigate the knowledge, attitude and behaviors of people about HPV infection and the HPV vaccine.

\section{Materials and Methods}

A total of 836 participants who were admitted to the internal medicine, gynecology and obstetrics, urology, orthopedics and ophthalmology outpatient clinics of a secondary care hospital between June 2019 and December 2019 were included in this cross-sectional study.
Those who did not want to participate in the study and those who were younger than 18 were excluded from the study. An informed consent form was obtained from all patients. Voluntary men and women between the age of 18 and 65 were included in the study. The study was prospectively performed and approved by the ethics committee of Mustafa Kemal University, Tayfur Ata Sökmen Faculty of Medicine (ethics committee number: 2020/21).

A questionnaire including 3 parts was prepared by the researchers after they assessed the related studies in the literature. The participants were informed about the study before the interviews and the questionnaire forms were completed by all the participants in a different outpatient clinic room for privacy. The participants anonymously completed the questionnaire forms within 2-3 minutes on average.

Participants' demographic data such as age, gender, marital status, number of children, educational status, profession, monthly income and whether they smoked or not were questioned in the first part of the questionnaire including 3 parts. Official minimum wage (about 272.61 US dollars [1 USD= 8.52 Turkish Liras in November 2020]) was used to differentiate low, medium and high income. In the second part, participants' level of knowledge about HPV (whether they regularly have gynecological exams, which contraception method they use, transmission route of HPV infection, who are affected by the infection and how to avoid HPV infection) were questioned. The answers were "yes" and "no" or "correct" or "false". In the third part, participants' level of knowledge about the HPV vaccine (general information about the vaccine, efficacy of the vaccine, its side effects, its safety, whether they will get the vaccine or not, and if the answer is "no", why they are anti-vax) were questioned. The answers were "yes" and "no" or "correct" or "false". Explanation options were given for "yes" and "no" answers and it was stated that patients could choose more than one option.

The data were analyzed with the SPSS 20.0 (Statistical Package for the Social Sciences Inc.; Chicago, IL, the USA) software program. Statistical evaluation was made as mean \pm standard deviation (mean $\pm S D$ ), and as percentile values.

\section{Results}

Participants who were admitted to various outpatient clinics of a secondary care hospital between June 2019 and December 2019 and who met the inclusion criteria were included in the study. Out of 1,205 participants, 232 participants were not able to understand and speak Turkish language well enough due to their recent immigration. In addition to those, participants who had adolescent pregnancy $(n=42)$ and those who could not adequately complete their questionnaires $(n=95)$ were excluded. A total of 836 participants were included in the statistical analysis. 
Demographic data of the participants are listed in Table 1. The mean age of the participants was $36.29 \pm 9.03$ and $86 \%$ were female. $74 \%$ of the participants were married and $44 \%$ were university graduates, $44 \%$ had a master's degree. The income of 638 patients (76\%) was more than 4,000 Turkish liras.

Table 1. Demographic Information of Participants

\begin{tabular}{|c|c|c|c|}
\hline \multicolumn{2}{|c|}{ Socio-demographic Data } & \multirow{2}{*}{$\begin{array}{c}\mathbf{n} \\
232\end{array}$} & \multirow{2}{*}{$\begin{array}{c}\% \\
27.75\end{array}$} \\
\hline \multirow{4}{*}{ Age } & $18-30$ & & \\
\hline & $30-45$ & 473 & 56.57 \\
\hline & $45-65$ & 131 & 15.66 \\
\hline & Mean $\pm S D$ & \multicolumn{2}{|c|}{$36.29 \pm 9.03$} \\
\hline \multirow{4}{*}{ Number of children } & $0-2$ & 772 & 92.34 \\
\hline & $3-5$ & 63 & 7.53 \\
\hline & $>5$ & 1 & 0.12 \\
\hline & Mean $\pm S D$ & \multicolumn{2}{|c|}{$1.15 \pm 1.02$} \\
\hline \multirow{2}{*}{ Gender } & Female & 722 & 86.36 \\
\hline & Male & 114 & 13.64 \\
\hline \multirow{3}{*}{ Marital Status } & Single & 173 & 20.69 \\
\hline & Divorced/Widow & 37 & 4.43 \\
\hline & Married & 626 & 74.88 \\
\hline \multirow{6}{*}{ Education } & None & 3 & 0.36 \\
\hline & Primary & 8 & 0.96 \\
\hline & Middle & 14 & 1.67 \\
\hline & High & 65 & 7.78 \\
\hline & University & 370 & 44.26 \\
\hline & Master's degree & 376 & 44.98 \\
\hline \multirow{5}{*}{ Employment Status } & Housewife & 230 & 27.51 \\
\hline & Unemployed & 15 & 1.79 \\
\hline & Part-time employee & 120 & 14.35 \\
\hline & Full-time employee & 430 & 51.43 \\
\hline & Other & 41 & 4.90 \\
\hline \multirow{4}{*}{ Income } & Less than minimum wage & 51 & 6.10 \\
\hline & Minimum wage & 25 & 2.99 \\
\hline & 2,000-4,000 Turkish Liras & 122 & 14.59 \\
\hline & More than 4,000 Turkish Liras & 638 & 76.32 \\
\hline \multirow{2}{*}{ Smoking } & Yes & 158 & 18.90 \\
\hline & No & 678 & 81.10 \\
\hline
\end{tabular}

The knowledge levels of the participants on HPV are examined in Table 2. Although 26\% ( $n: 225$ ) of the participants said that they went to gynecological examination at regular intervals, $73 \%$ ( $n: 611$ ) said that they never went for a follow-up. A total of $73 \%$ of the participants ( $n: 613$ ) said "Yes, it is infected through sexual intercourse" to the question "Do you know how HPV is infected?", and 25\% (n: 214) said "No". Although 67\% (n: 565) said "Yes" to the question "Do you know the relation between HPV and cervical cancer?", 578 participants (69\%) said that the statement "We can protect ourselves from HPV infection with oral contraceptives (i.e. birth control medication) and with monthly injections" is "False", and 65\% (n: 548) of the participants said that the statement "We can protect ourselves from HPV infection with barrier methods such as condom" is "Correct".

Participants' levels of knowledge about the HPV vaccine are listed in Table 3. Of the participants, 71\% $(n=594)$ answered the question "Do you know cervical cancer is a disease that can be prevented by the HPV vaccine?" as "Yes," while $56 \%(n=336)$ of the participants stated that they heard the HPV vaccine from their physicians and $20 \%$ $(n=122)$ stated that they learned about it from the internet. Of the participants, $8 \%$ knew that the HPV vaccine was not included in the vaccination program of the Ministry of Health. $43 \%(n=365)$ of participants stated that they had no intention of having the HPV vaccine for themselves, their wife/husband or their children. While $11 \%(n=96)$ of the participants answered the question "Each vaccine costs about 300-400 Turkish liras and is not covered by the government. Do you think of having the vaccine for your child in that condition?" as "I would not have the vaccine even if it was covered free of charge by the government" $31 \%(n=264)$ answered as "I would think of having the vaccine if it was covered by the government." While $10 \%$ $(n=88)$ answered as "I would have the vaccine if it cost less than 100 Turkish liras" 51\% ( $n=429)$ answered as "I would have the vaccine under any condition." While 12 participants (1\%) were against all the vaccines, 31 participants $(3 \%)$ stated that the HPV vaccine was not safe. While $25 \%$ $(n=211)$ of the patients stated that they did not have sufficient information about the vaccine, $15 \%(n=130)$ stated that they did not have the vaccine because of its high cost.

\section{Discussion}

This cross-sectional descriptive study aimed to assess the knowledge, attitudes and behaviors of people about HPV infection and the HPV vaccine. $23 \%(n=196)$ of the participants stated that they had never heard of HPV before and $43 \%(n=365)$ stated that they had no intention of having the HPV vaccine for themselves, their wife/husband or their children. While the rate of the participants who did not want to have the HPV vaccine in any condition was $11 \%$ the rate of the participants who were against all vaccines was $1 \%$.

Cervical cancer is among the diseases that can be diagnosed early and prevented by vaccines (9). While HPV infections cause nearly all cervical and anal cancers they account for about $70 \%$ of vulvar, vaginal and oropharyngeal cancers and $60 \%$ of penile cancers (10). While the prevalence of HPV is $11 \%$ in the world, it can vary according to the regions within countries. The prevalence of HPV is $33 \%$ in East Africa, 13\% in Central America, 10\% in Northern Europe and $1 \%$ in West Asia (11). However, the risk of diseases that are sexually transmitted is increasing due to the increasing risk factors such as the decreasing average age of sexual intercourse worldwide, having more than one sexual partner and smoking (12). While the rate of those 
who had knowledge of HPV infection and vaccine was reported as $68 \%$ in a study on American women (13), the rate of having knowledge of HPV was reported as $13 \%$ and the rate of hearing of the HPV vaccine was reported as $6 \%$ in a study on Uighur women (14).

Table 2. Participants' Level of Knowledge about HPV

\begin{tabular}{|c|c|c|c|}
\hline Questions & & $\mathbf{n}$ & $\%$ \\
\hline \multirow{5}{*}{$\begin{array}{l}\text { Do you regularly have gynecological exams? (If the participant is } \\
\text { male, their wife is meant here) } \\
\text { If your answer is yes, how often do you have gynecological exams? }\end{array}$} & Yes & 225 & 26.91 \\
\hline & Once in 6 months & 40 & 17.78 \\
\hline & - I have it at longer intervals. & 58 & 25.78 \\
\hline & - $\quad$ Once a year & 127 & 56,44 \\
\hline & No & 611 & 73.09 \\
\hline \multirow[t]{7}{*}{ Which contraception method do you use? } & I use monthly or 3-monthly injections. & 4 & 0.48 \\
\hline & I use birth control pills. & 53 & 6.34 \\
\hline & I use the withdrawal method. & 83 & 9.93 \\
\hline & I do not use any of the methods. & 307 & 36.72 \\
\hline & I use a condom. & 256 & 30.62 \\
\hline & I use IUD. & 95 & 11.36 \\
\hline & I had tubal ligation. & 38 & 4.55 \\
\hline \multirow[t]{4}{*}{ Do you know how Human Papillomavirus (HPV) is transmitted?* } & Yes, it is sexually transmitted. & 613 & 73.32 \\
\hline & $\begin{array}{l}\text { Yes, it is transmitted through pool and seawater } \\
\text { or toilets. }\end{array}$ & 83 & 9.92 \\
\hline & Yes, it is transmitted through blood. & 46 & 5.50 \\
\hline & No, I don't know. & 214 & 25.60 \\
\hline \multirow[t]{2}{*}{ Have you heard of Human Papillomavirus (HPV) before? } & Yes & 640 & 76.56 \\
\hline & No & 196 & 23.44 \\
\hline \multirow[t]{3}{*}{ Do you know the cause of cervical cancer? } & Yes & 571 & 68.30 \\
\hline & No & 161 & 19.26 \\
\hline & I have no idea. & 104 & 12.44 \\
\hline \multirow{3}{*}{$\begin{array}{l}\text { Do you know the relationship between Human Papillomavirus } \\
\text { (HPV) and cervical cancer? }\end{array}$} & Yes & 565 & 67.58 \\
\hline & No & 169 & 20.22 \\
\hline & I have no idea. & 102 & 12.20 \\
\hline \multirow[t]{4}{*}{ Who are affected by Human Papillomavirus (HPV)? } & I have no idea about this. & 201 & 24.04 \\
\hline & Both women and men. & 540 & 64.59 \\
\hline & Only men. & 2 & 0.24 \\
\hline & Only women. & 93 & 11.12 \\
\hline \multirow{3}{*}{$\begin{array}{l}\text { We can prevent HPV infection with contraception methods such as } \\
\text { oral contraceptives (birth control pills) and monthly injectables. }\end{array}$} & I don't know. & 209 & 25.00 \\
\hline & Correct & 49 & 5.62 \\
\hline & False & 578 & 69.02 \\
\hline \multirow{3}{*}{$\begin{array}{l}\text { It is possible to prevent HPV infection with barrier methods such as } \\
\text { a condom. }\end{array}$} & I don't know. & 198 & 23.68 \\
\hline & Correct & 548 & 65.55 \\
\hline & False & 90 & 10.70 \\
\hline
\end{tabular}

In our study, while the rate of participants who had knowledge of HPV was $76 \%$, the rate of those who knew that cervical cancer could be prevented by the HPV vaccine was $71 \%$. Our study has a similar rate to that of American women. The rate in the study on Uighur women is quite low compared to the rates in our study. The reason for this huge difference may be differences in the educational status of the participants. Although there is no exact data on HPS vaccine rates in Turkey, it is known that approximately 60,000 women $(0.17 \%$ of the total women population) received HPV vaccination in the 9-year period from 2007 to August 2016 (15).

It was reported in another study that awareness of HPV infection and vaccine increased by educational level (16). In our study, $44 \%$ of the participants were university graduates, and $44 \%$ had a master's degree, which means the educational level was quite high. In a study in South Korea, the rate of people who wanted to have the vaccine was $55 \%$ and $77 \%$ of these participants were women (2). Only 133 (13\%) out of 1,000 patients included in the same study knew the relationship of HPV with cervical cancer
(2). In another study in China, $26 \%$ of the participants knew that HPV was a risk factor for cervical cancer (17). In our study, the rate of those who knew the relationship between HPV and cervical cancer was $67 \%$.

The reason why these rates are different in the literature may be varying educational levels and awareness of countries about HPV infection and its vaccine, differences in country policies, differences in information campaigns of governments about HPV infection and its vaccine, and differences in economic development levels of countries. As HPV, which is a highly contagious infection, is sexually transmitted, sexually active people must take general precautions in order to prevent this infection and know that condom use may not be sufficient to prevent transmission. According to the results of the questionnaire in our study, $10 \%$ of the participants chose the "False" option for the statement "It is possible to prevent HPV infection with barrier methods such as a condom". In addition, while $25 \%$ of the participants chose the "I don't know" option for the statement "We can prevent HPV in- 
fection with contraception methods such as oral contraceptives (birth control pills) and monthly injectables" 69\% stated that this statement was "False". In a study in Italy, that statement was found as "False" by $36 \%$ of the participants (18). Although awareness levels in our study about "oral contraceptives have no protection against HPV infection" were found higher than the awareness in the study in Italy, the rate (25\%) of the participants who said "I don't know" was considerable. These results have shown that people need to be informed that oral contraceptives are not protective against HPV infection.

In another study, a decrease in genital warts at a rate of $90 \%$, in HPV $6,11,16$, and 18 infections at a rate of $90 \%$ and in high-grade cervical cytological abnormalities at a rate of $85 \%$ was determined in countries which included the Quadrivalent HPV vaccine in their national vaccination programs (19). In our study, $71 \%$ of the participants answered the question "Do you know cervical cancer is a disease that can be prevented by the HPV vaccine?" as "Yes" 28\% answered "No". In a study in Thailand, which is one of the countries where cervical cancer is the most common and the HPV vaccine is not included in the national vaccination program, a relationship was found between parents' level of knowledge and beliefs about the HPV vaccine and acceptability of the vaccine (20).

Table 1. Participants' level of knowledge about the HPV vaccine

\begin{tabular}{|c|c|c|c|}
\hline Questions & & $n$ & $\%$ \\
\hline \multirow{2}{*}{$\begin{array}{l}\text { Do you know that cervical cancer is a disease that be pre- } \\
\text { vented by the HPV vaccine? }\end{array}$} & Yes & 594 & 71.05 \\
\hline & No & 242 & 28.95 \\
\hline \multirow{4}{*}{ How did you hear about the HPV vaccine?** } & Friends & 42 & 7.07 \\
\hline & My physician informed me. & 336 & 56.57 \\
\hline & Internet & 122 & 20.54 \\
\hline & Television, magazine, newspaper & 94 & 15.82 \\
\hline \multirow{8}{*}{$\begin{array}{l}\text { Did you have the HPV vaccine for yourself, your wife/hus- } \\
\text { band or your child? }{ }^{* *}\end{array}$} & Yes & 594 & 71.05 \\
\hline & - $\quad$ Yes, my wife/husband had. & 4 & 0.67 \\
\hline & - $\quad$ Yes, I had. & 70 & 11.78 \\
\hline & - Yes, both I and my wife/husband had. & 1 & 0.17 \\
\hline & - $\quad$ Yes, my daughter had. & 20 & 3.37 \\
\hline & - Yes, my son had. & 3 & 0.51 \\
\hline & - Yes, both my daughter and my son had. & 3 & 0.51 \\
\hline & 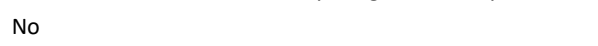 & 493 & 83.00 \\
\hline \multirow{3}{*}{$\begin{array}{l}\text { The HPV vaccine prevents genital warts (Condyloma) and } \\
\text { cervical cancer. }\end{array}$} & I don't know. & 216 & 25.83 \\
\hline & Correct & 604 & 72.24 \\
\hline & False & 17 & 2.03 \\
\hline \multirow{3}{*}{$\begin{array}{l}\text { The HPV vaccine prevents all the sexually transmitted dis- } \\
\text { eases. }\end{array}$} & I don't know. & 228 & 27.27 \\
\hline & Correct & 80 & 9.57 \\
\hline & False & 528 & 63.16 \\
\hline \multirow{3}{*}{$\begin{array}{l}\text { The HPV vaccine is included in the vaccination program of } \\
\text { the Ministry of Health. }\end{array}$} & I don't know. & 275 & 32.89 \\
\hline & Correct & 74 & 8.85 \\
\hline & False & 487 & 58.25 \\
\hline \multirow{3}{*}{$\begin{array}{l}\text { After the HPV vaccine, side effects such as pain, rash, red- } \\
\text { ness at injection site and headache may occur. }\end{array}$} & I don't know. & 438 & 52.39 \\
\hline & Correct & 340 & 41.6 \\
\hline & False & 58 & 6.94 \\
\hline Will you have the HPV vaccine for yourself, your wife/hus- & Yes, I will. & 471 & 56.33 \\
\hline band, your son or your daughter? & No, I won't. & 365 & 43.66 \\
\hline There are two types of the HPV vaccine. It must be adminis- & $\begin{array}{l}\text { I would not have the vaccine even if it was covered by the } \\
\text { government. }\end{array}$ & 96 & 11.48 \\
\hline $\begin{array}{l}\text { tered in } 3 \text { doses within } 6 \text { months in order to prevent cervical } \\
\text { cancer. Each vaccine costs about } 300-400 \text { Turkish liras and is }\end{array}$ & $\begin{array}{l}\text { I would think of having the vaccine if it was covered free of } \\
\text { charge by the government. }\end{array}$ & 264 & 31.57 \\
\hline not covered by the government. Do you think of having the & I would have the vaccine if it cost less than 100 Turkish liras. & 88 & 10.52 \\
\hline Vaccine tor your chila in that conaition?: & I would have the vaccine in any condition. & 429 & 51.31 \\
\hline & I am against all vaccines. & 12 & 1.43 \\
\hline & I do not find the HPV vaccine safe. & 31 & 3.70 \\
\hline & $\begin{array}{l}\text { The number of sexual partners can be increased after hav- } \\
\text { ing the HPV vaccine. }\end{array}$ & 12 & 1.43 \\
\hline Why are you against having the HPV vaccine? & I don't think the HPV vaccine is necessary. & 59 & 7.05 \\
\hline & It is very expensive. & 130 & 15.55 \\
\hline & I don't have sufficient information about the vaccine. & 211 & 25.23 \\
\hline & I think the vaccine has side effects. & 44 & 5.26 \\
\hline & If I have the vaccine, it may be hard to have a child. & 13 & 1.55 \\
\hline
\end{tabular}

${ }^{*}$ More than one answer was given.

**Answered by those who answered the question "Do you know that cervical cancer is a disease that can be prevented by the HPV vaccine?" as "yes." 
As the catch-up age range of the HPV vaccine is between 13 and 26, the views of the parents are important to increase vaccination in this age range. While $96 \%$ of the parents accepted their daughters to have the vaccine in Indonesia this rate was found as $75 \%$ in America $(21,22)$. In Brazil, the rate of parents who accepted their daughters at the age of 18 and below to have the vaccine was $92 \%$ and the rate of those who accepted their sons to have the vaccine was $86 \%$ (23). As the HPV vaccine has not been included in the national vaccination program in our country parents' knowledge and views about the vaccine are quite important for the feasibility of the vaccine. Therefore, informing and educating parents are important.

While $56 \%$ of the participants in our study stated that they heard about the HPV vaccine from their physicians $20 \%$ learned it from the internet and $15 \%$ heard it via television, magazine or newspaper. Educating and informing people are of great importance to increase the vaccination rates. Reasons such as the busy schedule of physicians, lacking of knowledge about the vaccine, hesitations on recommending a vaccine and absence of the HPV vaccine in the routine vaccination program of the Ministry of Health may be decreasing the rates of recommending the vaccine among physicians. Additionally, using tools such as social media, television and the internet and preparing educational videos such as public service announcements may be helpful in increasing knowledge and awareness.

Vaccines in the routine vaccination programs of the countries are generally covered free of charge by governments. While people pay their vaccine fees in Austria only a certain percentage of the vaccine is paid by people in Belgium and France (25\% in Belgium and 35\% in France) (24). Vaccination programs in the European Union countries are generally carried out by community health services and are school-based. In 7 countries, including the UK, Denmark, Italy, Luxemburg, Netherlands, Portuguese, and Romania, catch-up vaccines are covered by the government. Portuguese and the UK have the highest rate of vaccination among the 7 countries from which data can be obtained and this rate is above $80 \%(25)$.

Although $72 \%$ of the participants in our study knew that the HPV vaccine was protective against condyloma and cervical cancer $83 \%$ did not have the vaccine. In addition, $43 \%$ of the participants stated that they had no intention of having the vaccine for themselves, their wife/husband or their children. Of the participants, 31\% stated that they would have the vaccine if it was covered free of charge by the government. Various policies carried out by the government and investments in health service areas to increase vaccination rates can help vaccination rates to increase. Vaccination rates are less than expected, which may be because vaccines are expensive and not covered by the government and $10 \%$ of the participants in our study stated that they would have the vaccine if it cost less than 100 Turkish liras. This rate can vary according to the economic conditions of people living in different regions of the world or country. The income of $76 \%$ of the participants in our study was more than 4,000 Turkish liras (the official minimum wage is about 272.61 USD). This may be associated with our hospital serving people with a high socio-cultural and income level. The results would be different in studies including participants with a lower income level.

The first country to initiate the national HPV vaccination program supported by the government in 2007 was Australia (25). In a study in Melbourne, the rate of new genital warts after 2007 decreased from $18 \%$ to $1 \%$ in women and from $22 \%$ to $2 \%$ in heterosexual men under the age of 21 (26). It is considered that no cervical cancer cases will be detected within 10-20 years with vaccination and HPV-based screening in Australia. The Program for Appropriate Technology in Health (PATH) initiated a vaccination campaign in Uganda, India, and Vietnam between 2006 and 2010 (27). In school-based vaccination programs in Uganda and Vietnam, vaccination rates reached up to $83 \%-96 \%$. Vaccination rates in India reached up to $77 \%-80 \%$ in school- and health center-based programs (27). The Global Alliance for Vaccines and Immunization (GAVI) is planning to decrease the cost of the vaccine and vaccinate more than 30 million girls in more than 40 countries at the end of 2020 starting with African countries (28). A decrease in cervical cancer-associated deaths is estimated at up to the rates of $76 \%$ with HPV vaccination programs that will be performed in nearly $100 \%$ vaccination rate and efficacy (29). A 70\% vaccination coverage in poor countries is estimated to be sufficient in decreasing the lifetime cancer risk at a rate between $31 \%$ and $60 \%$ (30).

There is a lack of trust in vaccines both in our country and in the world. The number of people who oppose vaccines including routine vaccines has been increasing recently both in our country and in the world $(31,32)$. Lobao et al. (23) asserted in their study that the reason of people refusing to have the HPV vaccine may be that they found the HPV vaccine unsafe, that it could cause severe reactions and side effects, that especially girls between the ages of 9 and 13 were too young for the vaccine and that the HPV vaccine may cause their sexual activity to start at an earlier age in girls. Moreover, it has been reported in the literature that the most common factors obstructing the vaccination are its high cost, the belief that vaccination in adolescents will cause sexual activity to start at an earlier age and the effectiveness of religious and social beliefs (33). In some studies, the reason for refusing the vaccine has been reported as the participants do not need the vaccine because they already have a monogamous life (34). In our study, $1 \%$ of the participants stated that they did not think of having the vaccine because the number of sexual partners could increase after the HPV vaccine. Similarly, families stated in another study that they did not want to have the vaccine because they thought the 
HPV vaccine would increase the sexual activity of their daughters (12\%) and the risk of unprotected sexual intercourse (18\%) (35). In our study, the most common reason for the participants opposing the vaccine was that they did not have sufficient information about the vaccine (25\%), the second most common reason was that they found the vaccine expensive (15\%). Some studies in literature pointed out the increase in acceptability of the vaccine after giving information about the HPV vaccine (34). Having sufficient knowledge of the HPV infection and vaccine is important for individuals in the process of deciding whether to have the vaccine. In our study, $25 \%$ of the participants refused to have the vaccine because they did not have sufficient information about the vaccine.

This study has some limitations. The first one is that no standardized and accepted questionnaire was used in our study, but our data collection form was not designed to measure the severity of a medical condition or assess the response to treatment, therefore, we do not think this is a limiting factor. The second is that we cannot make a general assessment with the available results as our study is a single-center study. The third is that differences in socioeconomic characteristics of the participating population may have affected the results.

HPV infection causes cervical cancer and increases the health costs of countries. However, it is a disease that can be prevented by vaccine and decreases costs by contributing highly to the country's economy in case the disease is prevented with the vaccine. We believe that raising awareness and increasing the sensitivity of physicians on such an important issue will contribute to the literature.

\section{Conclusion}

Although efforts on this issue continue across the country, they are not at the desired level yet. Considering the fact that the incidence of HPV is increasing each day, it must be kept in mind that it is an issue to be taken into account. There is still a lack of knowledge among people that cervical cancer is a disease that can be prevented by the HPV vaccine, how the HPV virus is transmitted and what precautions must be taken. This is mainly because the vaccine has not been included in the routine vaccination program in our country, healthcare workers do not sufficiently inform patients about the HPV vaccine and infection and the cost of the vaccine is high relative to the conditions of our country. The underlying reasons why institutions or workers who provide healthcare insufficiently inform people about the HPV vaccine can be examined in detail.

Ethical Approval: The study was prospectively performed and approved by the ethics committee of Mustafa Kemal University, Tayfur Ata Sökmen Faculty of Medicine (ethics committee number: 2020/21).

\section{Author Contributions:}

Concept: G.T., G.K.

Literature Review: G.T., Y.S.

Design : G.T., G.K., Y.S.

Data acquisition: G.K.

Analysis and interpretation: G.T, G.K.

Writing manuscript: G.T, Y.S.

Critical revision of manuscript: G.T, G.K.

Conflict of Interest: The authors have no conflicts of interest to declare.

Financial Disclosure: Authors declared no financial support.

\section{References}

1. Karaçor T, Barut MU, Peker N, and Sak ME. Yüksek Riskli HPV Pozitif Sitolojik Sonuçların, Kolposkopik Biyopsi Sonuçları İle Karşılaştırılması. Harran Üniversitesi Tıp Fakültesi Derg 2019; 16:540-544.

2. Oh JK, Lim MK, Yun EH, Lee EH, and Shin HR. Awareness of and attitude towards human papillomavirus infection and vaccination for cervical cancer prevention among adult males and females in Korea: A nationwide interview survey. Vaccine 2010; 28:1854-1860.

3. International Agency for Research on Cancer. GLOBOCAN 2018. Global Cancer Observatory. 2018; [cited 2019 Sep 28]. Available from: URL: https://gco.iarc.fr/\%0AGoogle Scholar

4. Urman $\mathrm{CO}$ and Gottlieb AB. New viral vaccines for dermatologic disease. J Am Acad Dermatol 2008; 58:361370.

5. World Health Organization W. Draft: Global Strategy towards eliminating cervical cancer as a public health problem. WHO press. 2020.

6. İncebıyık A. HPV Aşıları. Harran Üniversitesi Tıp Fakültesi Derg 2012; 9:68-70.

7. Ulus B. Current Approaches in Human Papillomavirus Vaccination. J Obs Womens Heal Dis Nurs-Special Top 2015; 1:47-50.

8. Brisson M, Kim JJ, Canfell K, Drolet M, Gingras G, Burger EA, et al. Impact of HPV vaccination and cervical screening on cervical cancer elimination: a comparative modelling analysis in 78 low-income and lower-middle-income countries. Lancet 2020; 395:575-590.

9. Uyanıkoğlu H, Numanoğlu C, and Gülkılık A. Servikal Kanser Taramasında Asetikasit Sonrası İnspeksiyon ile Servikal Smearin Karşılaştırılması Comparison of Visual Inspection of Cervix with Acetic Acid and Smear for Cervical Cancer Screening. Harran Üniversitesi Tıp Fakültesi Derg 2016; 13:1-8.

10. Laura J. Viens, S. Jane Henley, Meg Watson, Lauri E. Markowitz, Cheryll C. Thomas, Trevor D.Thompson HR and MS. Human Papillomavirus-Associated Cancers - United States, 2008-2012. Morb Mortal Wkly Rep 2016; 65:661-666.

11. Formana D, de Martel C, Lacey CJ, Soerjomatarama I, Lortet-Tieulent J, Bruni L, et al. Global burden of human papillomavirus and related diseases. Vol. 30, Vaccine. Elsevier; 2012; 12-23.

12. Çetin $O$, Verit FF, Keskin $S$, Zebitay $A G$, Deregözü A, Usta $T$, et al. Knowledge levels of adolescent girls about human papilloma virus and its vaccine. Turk Pediatr Ars 2014; 49:142-147.

13. Blake KD, Ottenbacher AJ, Finney Rutten LJ, Grady MA, 
Kobrin SC, Jacobson RM, et al. Predictors of human papillomavirus awareness and knowledge in 2013: Gaps and opportunities for targeted communication strategies. Am J Prev Med 2015; 48:402-410.

14. Abudukadeer A, Azam S, Mutailipu AZ, Qun L, Guilin G, and Mijiti S. Knowledge and attitude of Uyghur women in Xinjiang province of China related to the prevention and early detection of cervical cancer. World J Surg Oncol 2015; 13:1-7.

15. Topçu S, Ulukol B, Emüler D, Topçu H, ... GP-JCA, and 2017 U. Awareness of Human Papilloma Virus and acceptability of Human Papilloma Virus vaccine: A survey of Turkish university students. J Clin Anal Med 2017; 8.

16. Agurto I, Bishop A, Sánchez G, Betancourt Z, and Robles $S$. Perceived barriers and benefits to cervical cancer screening in Latin America. Prev Med (Baltim) 2004; 39:9198.

17. Xu C, Zhang $\mathrm{W}, \mathrm{Wu} \mathrm{M}$, and Zhang S. Knowledge of cervical cancer among 25-54-year-old women in Beijing. J Cancer Educ 2011; 26:555-559.

18. Di Giuseppe G, Abbate R, Liguori G, Albano L, and Angelillo IF. Human papillomavirus and vaccination: Knowledge, attitudes, and behavioural intention in adolescents and young women in Italy. Br J Cancer 2008; 99:225-229.

19. Garland SM, Kjaer SK, Muñoz N, Block SL, Brown DR, Dinubile MJ, et al. Impact and effectiveness of the quadrivalent human papillomavirus vaccine: A systematic review of 10 years of real-world experience. Clin Infect Dis 2016; 63:519-527.

20. Grandahl M, Paek SC, Grisurapong $S$, Sherer $P$, Tydén $T$, and Lundberg P. Parents' knowledge, beliefs, and acceptance of the HPV vaccination in relation to their sociodemographics and religious beliefs: A cross-sectional study in Thailand. Grce M, editor. PLoS One 2018; 13:e0193054.

21. Constantine NA and Jerman P. Acceptance of Human Papillomavirus Vaccination among Californian Parents of Daughters: A Representative Statewide Analysis. J Adolesc Heal 2007; 40:108-115.

22. Jaspers $L$, Budiningsih $S$, Wolterbeek $R$, Henderson FC, and Peters AAW. Parental acceptance of human papillomavirus (HPV) vaccination in Indonesia: A cross-sectional study. Vaccine 2011; 29:7785-7793.

23. Mendes Lobão W, Duarte FG, Burns JD, de Souza Teles Santos CA, Chagas de Almeida MC, Reingold A, et al. Low coverage of HPV vaccination in the national immunization programme in Brazil: Parental vaccine refusal or barriers in health-service based vaccine delivery? Angelillo IF, editor. PLoS One 2018; 13:e0206726.

24. Şahbaz $A$ and Erol O. HPV aşi uygulamalari. Turk Jinekoloji ve Obstet Dern Derg 2014; 11:126-130.

25. Flagg EW, Schwartz $R$, and Weinstock $H$. Prevalence of anogenital warts among participants in private health plans in the United States, 2003-2010: Potential impact of human papillomavirus vaccination. Am J Public Health 2013; 103:1428-1435.

26. Read TRH, Hocking JS, Chen MY, Donovan B, Bradshaw CS, and Fairley CK. The near disappearance of genital warts in young women 4 years after commencing a national human papillomavirus (HPV) vaccination programme. Sex Transm Infect 2011; 87:544-547.
27. LaMontagne $D$, Barge $S$, Thi Le $N$, Mugisha E, Penny M, Gandhi S, et al. Human papillomavirus vaccine delivery strategies that achieved high coverage in low- and middle-income countries. Hum papillomavirus vaccine Deliv Strateg that achieved high Cover low- middle-income Ctries 2011; 89:821-830.

28. Kane MA, Serrano B, De Sanjosé S, and Wittet S. Implementation of human papillomavirus immunization in the: Developing world. Vaccine 2012; 30:F192-F200.

29. Kohli, M., Ferko, N., Martin, A., Franco, E. L., Jenkins, D., Gallivan, S., ... \& Drummond M. Estimating the long-term impact of a prophylactic human papillomavirus 16/18 vaccine on the burden of cervical cancer in the UK. Br J Cancer 2007; 96:143-150.

30. Hopkins TG and Wood N. Female human papillomavirus (HPV) vaccination: Global uptake and the impact of attitudes. Vaccine 2013; 31:1673-1679.

31. Pulatoğlu Ç and Turan G. Women's knowledge and beliefs towards vaccination for influenza during pregnancy in turkey and underlying factors of misinformation: A single-centre cross-sectional study. Cent Eur J Public Health 2020; 28:124-129.

32. Turan $\mathrm{G}$ and Kul G. Tetanus immunization in pregnant women: the factors affecting maternal evaluation, tetanus vaccination and vaccination rate. Perinat J 2019; 27:137-142.

33. Boehner CW, Howe SR, Bernstein DI, and Rosenthal SL. Viral sexually transmitted disease vaccine acceptability among college students. Sex Transm Dis 2003; 30:774778.

34. Brewer NT and Fazekas KI. Predictors of HPV vaccine acceptability: A theory-informed, systematic review. Prev Med (Baltim) 2007; 45:107-114.

35. Marlow LAV, Waller J, and Wardle J. Parental attitudes to pre-pubertal HPV vaccination. Vaccine 2007; 25:1945-1952. 